\title{
The Development of Integrative Thematic Learning Tools Based on Problem Based Learning to Improve Critical Thinking of Students in Fourth Grade in Elementary School
}

\author{
Lilik Sabdaningtyas ${ }^{1 *} \quad$ Alben Ambarita ${ }^{2}$ \\ Faculty of Teacher Training and Education, University of Lampung \\ St. S. Brojonegoro, No.1, Gedung Meneng, Bandar Lampung, Indonesia, 35145
}

\begin{abstract}
The purpose of this research and development is to develop and describe the feasibility and effectiveness of developing integrative thematic learning tools based on Problem Based Learning in improving students' critical thinking. This type of research is research and development that refers to Borg and Gall theory. The population of this study was the fourth-grade students of elementary schools in Argomulyo Village, Banjit District, and the sample was determined by a purposive sampling of 27 students. Data were collected through observation sheets, questionnaires, and test questions. The test instrument that used able to fulfills validity and reliability, taking into account the level of difficulty, and the different power of the questions. The data analysis technique used is the $\mathrm{n}$-Gain test to determine its effectiveness. The results of validating thematic learning tools based on Problem Based Learning are done by curriculum experts and learning experts. The results showed that the product development of integrated thematic learning tools based on Problem Based Learning produced is effective for use in the learning process for fourth-grade students. This is proved by the increase in student learning outcomes and students' critical thinking skills after using an integrative thematic learning tool based on Problem Based Learning.
\end{abstract}

Keywords: Learning Tools, Integrative Thematic, Problem Based Learning, Critical Thinking.

DOI: $10.7176 / \mathrm{JEP} / 10-30-04$

Publication date:October $31^{\text {st }} 2019$

\section{INTRODUCTION}

The role of basic education is very central and strategic laying the foundations of intelligence and character in students. Basic education has the responsibility to educate, so that people become cognitively, affective, and psychomotor intelligent. Minister of Education and Culture Regulation Number 65 of 2013 concerning Process Standards, teachers must organize learning processes that are "interactive, inspiring, fun, challenging, motivating students to participate actively, as well as providing sufficient space for initiative, creativity, and independence according to talent, interests, and physical and psychological development of students ". The main problem in education, including basic education, is the lack of quality of the learning process. The learning process is still oriented to how students master and memorize information and lack of opportunities to develop their thinking skills (Trianto, 2010: 5-6).

Empirically, the low quality of the learning process is supported by Tiarani's research (2013: 340), through an autoethnographic study it is concluded that the learning process carried out by elementary school teachers is still teacher-centered. Research Sutriningsih, et al (2014) that in mathematics learning activities, questions raised by teachers still require memorization and understanding. The teacher asks more questions relating to factual or procedural knowledge. Analysis, synthesis, and evaluative questions raised by the teacher to students are still very limited. Even though the questions asked by the teacher affect the thought process and student learning process.

The low quality of the learning process by teachers implies the low quality of student learning outcomes, especially seen from their critical thinking skills (high order thinking skills). The results of a study program for the International Student Assessment (Organization for Economic Co-operation and Development, 2011: 13; 19; 25 ) that aspects of the ability to read, mathematics, and Natural Sciences nearly $95 \%$ of Indonesian students only reached level 3, whereas other countries level 4, 5, and even level 6. The findings of Trends in International Mathematics and Science Study (Wahab, 2014: 13) that aspects of the reading ability of Fourth Grade Elementary School students, Mathematics and Natural Sciences skills of Eighth Middle School students, indicate more than $95 \%$ of Indonesian students are only able to reach the intermediate level, while almost $40 \%$ of Taiwanese students reach high and advance levels.

If the assumption that all children are created and born the same, the meaning of the findings above, allegedly the content and learning process carried out in Indonesia are not by international demands and standards. The content learned is more related to factual, conceptual, and procedural knowledge, but is less concerned with higher-order thinking skills. The learning approach used is more teacher-centered and gives less space for students to practice critical thinking skills. The results of a preliminary study questionnaire for Fourth- 
grade teachers of Public Elementary School 3 Argomulyo, Way Kanan, revealed that students' critical thinking skills were still low. Obtained that students difficulties, answer questions or solve problems to analyze and synthesize.

The low quality of learning is due to various factors, including teachers being less professional, starting from planning, implementing the process, and evaluating learning. That is, teachers are less able to prepare learning tools and implement them appropriately. Empirically, the fact of the low quality of teachers can be seen from the results of teacher competency tests by the Ministry of Education and Culture, measuring academic, pedagogical, social, and personality competencies. Of the 1.6 million teachers who took the teacher competency test, more than 1.3 million received grades of less than 60 (ranging from 0-100). Nearly 130,000 teachers received grades between 0 and 30. Even sadder, the test results showed that mastery of the material and the ability to educate elementary school teachers was the most disadvantaged (Kompas, Wednesday, July 8, 2015 , p. 11).

Departing from these empirical conditions, Permendikbud No. 65 of 2013 concerning Process Standards, requires teachers to make plans, implement processes and assess learning processes efficiently and effectively. Permendikbud No. 71 of 2013 concerning Teaching Textbooks and Teacher's Handbook for Primary and Secondary Education, has provided textbooks. When examined, some notes that need to be considered in relation to the guidebook are (1) the teacher's book has not explained the steps of learning in detail in accordance with the approach chosen, (2) the characters to be achieved are not clear and specific in the objectives and steps of learning, ( 3) assessment rubrics are incomplete. For this reason, it is necessary to improve the learning tools, so that the choice of approach is more detailed at the learning step. Ennis (Nitko \& Brookhart, 2011: 232) stated "Critical thinking is reasonable, reflective thinking that is focused on deciding what to believe or do". Uzuntiryaki-Kondakçi \& Çapa-Aydin (2013: 667), the characteristics of critical thinking are: (1) (contextsensitive) (2) can be developed through an effective guide. (3) related to metacognitive abilities. While Lumsdaine (1995: 253) argues the characteristics of critical thinking are (1) orientation to the process not the end result, (2) productive and positive activities, (3) contain emotional and rational aspects, and (4) based on curiosity, flexibility, and doubt.

The highest level of critical thinking ability in Bloom's taxonomy is to analyze, evaluate, and create (Moore \& Stanley, 2010: 10). Critical thinking ability raised in this study, with thoughts (1) Critical thinking ability is a necessity in the 21 st century era, by Neuman $(2011: 2)$ referred to as the information age, which is very easy to obtain knowledge requires the ability to think critically to sort out, choose, and process information or knowledge effectively and efficiently so that it is of use-value for the development of self, society, nation, and state. (2) empirically, the ability of students in critical thinking is still low. This is proved by the results of the Program for International Student Assessment and Trends in International Mathematics and Science Study as previously explained. To answer these needs, learning tools need to be developed according to needs through an approach based on student activities (student-centered). Critical thinking skills develop when students are actively involved in activities that involve thought processes. This is in line with the Minister of Education and Culture Regulation No. 65 of 2013 concerning Process Standards which emphasizes that the learning process must be centered on student activities supported by the application of a student-centered approach.

One approach to learning centered on student activities is the Problem-Based Learning approach. Torp \& Sage (2002: 15) interpret "Problem-based learning is focused, experiential learning (minds-on, hands-on) organized around the investigation and resolution of messy, real-world problems". Problem Based Learning as learning that requires the active involvement of students in the aspects of minds-on and hands-on by making the problem as a source of meaningful learning. Learning tools developed using the Problem Based Learning approach are problem-solving skills, critical thinking, and learning how to learn (Akinoğlu and Tandoğan, 2007: 71). By making problems a starting point for learning, students are encouraged to find effective solutions to problems, analyze, find, and synthesize through collaborative processes to find effective solutions. A learning environment like this can encourage the development of students' critical thinking skills so that students realize how to learn. The results of the research and development of integrative thematic learning tools based on Problem Based Learning to improve critical thinking of fourth-grade students, obtained the following results.

\section{RESEARCH METHODS}

The type of research using research and development refers to the theory of Borg \& Gall (1983: 772) on Reasearch-Based-Development according to the purpose of research, namely research procedures with the aim of developing and validating educational products developed. Borg and Gall (2003: 569-575) research and development procedures, namely research and information collecting, planning, developing preliminary form of product, preliminary field testing, main product revision, playing field testing, operational product revision, operational field testing, final product revision, and dissemination and implementation. The research and development carried out only reached the seventh step, because of the limitations of researchers, both in terms of time and cost. 
In this study, the R\&D model developed by Borg and Gall was later modified into three main steps according to Sukmadinata (2012: 184), namely (1) a preliminary study, (2) model development, (3) model testing. The study population was fourth grade students of the State Elementary School Banjit District who had implemented the 2013 curriculum, namely SDN 3 Argomulyo with 27 students. The sample was determined using purposive sampling with the consideration that SDN 3 Argomulyo as a school the 2013 curriculum implementation.

Data collection tools for the development of integrative thematic learning tools using a questionnaire, namely the validation of curriculum and learning experts covering aspects of material and media.

Learning outcomes are obtained from the results of the pretest and posttest learning using LKS (student worksheets) $\mathrm{PjBL}$ model oriented to project appraisal, using valid and reliable test instruments, and considering the level of difficulty and different power of questions. The multiple choice instrument is given a score of 1 for the correct answer and a score of 0 for the wrong answer. Learning outcomes of skills using observation sheets. Data analysis technique to see the effectiveness between the use of PBL-based integrative thematic learning tools in learning is done by analyzing the normalized average gain value with the n-Gain formula. The n-gain analysis that will be used in this study is based on the results of the pre-test and post-test. Hake (in Sundayana, 2015: 149) revealed that in order to know the effectiveness of a learning in conceptual understanding, an analysis of the average value of normalized gain was carried out.

\section{RESEARCH RESULTS AND DISCUSSION}

3.1 The Result Development of Integrative Thematic Learning Tools Based on Problem Based Learning to Improve Critical Thinking of Students in Fourth Grade in Elementary School

The Result Development of Integrative Thematic Learning Tools Based on Problem Based Learning to Improve Critical Thinking of Students in Fourth Grade in Elementary School, The following results are obtained.

\subsubsection{Research and Information Collecting}

Information was collected by observation and interviews with school principals and fourth grade SDN 3 Argomulyo teachers. The results of observations and interviews obtained information that (1) the quality of the learning process is still low. (2) The ability to think critically in low category students. (3) The ability of teachers to develop integrative thematic learning tools is still weak. (4) The systematic integration of thematic learning tools not yet prepared by the government. (5) The unavailability of integrative thematic learning tools based on the PBL approach in SDN 3 Argomulyo.

\subsection{2 planning}

Planning is done by analyzing the results of information gathering. The product to be developed is a learning tool consisting of a syllabus, lesson plans, student worksheets and assessment instruments. Furthermore, the authors systematically compile the basic competencies, indicators, and learning objectives developed in this study. The theme and sub-theme determined are theme 3, 'Care for Living Things' and sub-theme 1, 'Animals and Plants in My Home Environment' in Class IV.

\subsubsection{Development of the Initial Product Format}

The steps in developing a thematic-integrative learning tool product based on Problem Based Learning are as follows:

a. Arrangement of learning devices of thematic-integrative learning tools based on Problem Based Learning

The thematic-integrative learning tool product based on Problem Based Learning was developed as a learning device in the fourth grade on theme 3 (Care for Living Things), subtheme 1 (Animals and Plants in My Home Environment). The following is the initial product prototypes of the learning tools compiled. Syllabus, Learning Implementation Plan, and Student Worksheets (Cover, Preface, Table of Contents, Mapping of Basic Competencies, Instructions for Use, Description of Materials and Activities, Evaluation, Bibliography) and Test Instruments.

b. Product Validation and Product Revision

Product validation is carried out by curriculum experts to assess the validity of learning tools in the form of syllabus and Learning Implementation Plans. Next is the learning expert, that is the material expert and the media expert, to assess whether the Problem Based Learning Worksheet is rationally valid and effective to be used to improve student learning outcomes. The first is the assessment of curriculum experts, this assessment includes the assessment of learning tools in the form of syllabus and Thematic-integrative Learning Implementation Plan based on Problem Based Learning conducted by Lecturers at Lampung University. Based on the curriculum expert test, there are a number of things that need to be improved, that are (1) learning steps must refer to Problem Based Learning, (2) time allocation must be adjusted to the division of class hours, and (3) writing on the syllabus matrix, indicators must parallel to basic competencies.

Secondly, the assessment of learning experts conducted on the Problem Based Learning Student Worksheet product consisting of material experts and media experts. The two experts are Lecturers at Lampung University. Based on the learning expert test, several things need to be improved, that are (1) The cover is designed more 
interesting, (2) Core Competency needs to be added, and (3) the rice plant flow scheme in the material description needs to be clarified.

Third, is the Evaluation Validation Results, the test instrument to measure student learning outcomes before and after using teaching materials in the form of Problem Based Learning Student Worksheets, validated first with trials on 21 students in fourth grade in Public Elementary School 2 Argomulyo. from 50 questions tested there were 33 valid items. However, 30 items were used for the pretest and posttest in this study.

\subsubsection{Preliminary Field Testing}

The product trial is limited to small groups conducted to fourth-grade students in Public Elementary School 2 Argomulyo. The assessment by the small group was carried out by 9 people consisting of 3 people from the group with high initial ability, 3 people from the group with moderate ability, and 3 people from the low group. The product trial results are limited to small groups used to find out the improvement of learning outcomes, critical thinking skills, and the effectiveness of the use of integrative thematic learning tools based on Problem Based Learning. These are the following results of small group trials.

a. Learning outcomes

The product trial was limited to a small group conducted to fourth-grade students in Public Elementary School 2 Argomulyo. There are differences in learning outcomes before and after using a Problem Based Learning Worksheet. Improvements that occur before and after learning are calculated by the N-Gain formula, as follows:

Table 1. Learning outcomes

\begin{tabular}{|l|l|c|c|c|c|}
\hline \multirow{2}{*}{ No. } & \multicolumn{1}{|c|}{ Indicator } & \multicolumn{2}{c|}{ Test Score } & \multirow{2}{*}{ Criteria } \\
\cline { 3 - 4 } & & Pre-test & Post-test & N-Gain & \\
\hline 1 & Total students & 9 & 9 & & \\
\hline 2 & Amount of Values & 494 & 665 & & \\
\hline 3 & Average value & 54.8889 & 73.889 & \multirow{2}{*}{0,35} & \multirow{2}{*}{ Average } \\
\hline 4 & Highest Scores & 70 & 85 & & \\
\hline 5 & Lowest score & 35 & 45 & & \\
\hline 6 & Completeness Level & $55 \%$ & $78 \%$ & & \\
\hline
\end{tabular}

Based on the hypothesis test, the N-Gain calculation result is 0,35 in the medium category and students reach the KKM of $78 \%$ ( 7 students), then the Problem Based Learning-based Student Worksheet is effectively used in the fourth-grade student in Public Elementary School 2 Argomulyo.

b. Critical Thinking Ability Test Results

The results of the critical thinking ability test were obtained from student observations during the learning in the limited trial class. The following is a recapitulation of the results of students' critical thinking in small groups.

Table 2. Critical Thinking Ability Test Results

\begin{tabular}{|l|l|l|c|c|}
\hline No. & \multicolumn{1}{|c|}{ Score } & \multicolumn{1}{c|}{ Category } & Frequency & Percentage(\%) \\
\hline 1 & $81-100$ & Very Good & 1 & 11,1 \\
\hline 2 & $66-80$ & Good & 5 & 55,6 \\
\hline 3 & $51-65$ & Enough & 3 & 33,3 \\
\hline 4 & $0-50$ & Not Good & 0 & 0,0 \\
\hline \multicolumn{2}{|l|}{ Total } & 9 & 100,0 \\
\hline
\end{tabular}

Based on the table, it can be described that the critical thinking skills of 9 students in a small group there are 1 student $(11.1 \%)$ with a very good category, 5 students $(55.6 \%)$ with a good category, and 3 students $(33.3 \%)$ with enough categories. It can be interpreted that the ability to think critically is marked by the emergence of aspects that show indicators of critical thinking skills have been seen.

c. Victory, Ease, and Benefit Test Results

The test of attractiveness, convenience, and usefulness is done by spreading the student response questionnaire. The results of the students' responses to the Problem Based Learning Worksheet based on Problem are as follows:

Table 3. Victory, Ease, and Benefit Test Results

\begin{tabular}{|c|c|c|c|c|c|c|c|}
\hline \multirow{2}{*}{ No } & \multirow[t]{2}{*}{ Category } & \multicolumn{2}{|c|}{ Attractive } & \multicolumn{2}{|c|}{ Easiness } & \multicolumn{2}{|c|}{ Usefulness } \\
\hline & & $\mathrm{F}$ & $\%$ & $\mathrm{~F}$ & $\%$ & $\mathrm{~F}$ & $\%$ \\
\hline 1 & Very interesting / very easy / very useful & 4 & 44,4 & 2 & 22,2 & 6 & 66,7 \\
\hline 2 & Interesting / easy / useful & 3 & 33,3 & 7 & 77,8 & 3 & 33,3 \\
\hline 3 & Quite interesting / easy enough / quite useful & 2 & 22,2 & 0 & 0,0 & 0 & 0,0 \\
\hline 4 & Less attractive / less easy / less useful & 0 & 0,0 & 0 & 0,0 & 0 & 0,0 \\
\hline 5 & Not interesting / not easy / not useful & 0 & 0,0 & 0 & 0,0 & 0 & 0,0 \\
\hline & Average score & (Ver & $\begin{array}{l}17 \\
\text { eresting) }\end{array}$ & & (Easy) & (Ver & $\begin{array}{l}25 \\
\text { Useful) }\end{array}$ \\
\hline
\end{tabular}

In the table, it appears that the average aspect of attractiveness is 4.17 in the attractive category, the average aspect of convenience is 4.1 in the easy category, and the benefit aspect is 4.25 in the very useful category. Thus, 
Problem Based Learning Worksheet based on learning is good and feasible to be developed and tested in the next stage.

\subsubsection{Main Product Revision}

Shows that there is a significant improvement in learning outcomes and critical thinking skills, so that the product does not need revision, and is worth testing in large groups.

\subsubsection{Main Field Testing}

There are differences in learning outcomes before and after using a Problem Based Learning Worksheet. Improvements that occur before and after learning are calculated by the N-Gain formula, as follows.

Table 4. Extended Test Pretest and Posttest Score

\begin{tabular}{|c|l|c|c|c|c|}
\hline \multirow{2}{*}{ No. } & \multirow{2}{*}{ Indicator } & \multicolumn{3}{|c|}{ Test Score } & \multirow{2}{*}{ Criteria } \\
\cline { 3 - 4 } & & Pre-test & Post-test & N-Gain & \\
\hline 1 & Total students & 27 & 27 & & \\
\hline 2 & Amount of Values & 1539 & 1980 & & \\
\hline 3 & Average value & 57 & 73,3 & \multirow{2}{*}{0,37} & \multirow{2}{*}{ Average } \\
\hline 4 & Highest Scores & 75 & 90 & & \\
\hline 5 & Lowest score & 35 & 60 & & \\
\hline 6 & Completeness Level & $48 \%$ & $85 \%$ & & \\
\hline
\end{tabular}

Based on the hypothesis test, the N-Gain calculation result is 0.37 in the medium category and students reach Minimal Completeness Criteria by $85 \%$ (23 students). An increase in learning outcomes before and after using Worksheet based on Problem Based Learning in fourth-grade students in Public Elementary School 3 Argomulyo. Meanwhile, the results of the critical thinking ability test were obtained from the observation of students during the learning process in the limited trial class. The following is a recapitulation of the results of students' critical thinking skills in large groups.

Table 5. Results of critical thinking skills of large group students

\begin{tabular}{|c|c|c|c|c|}
\hline No. & Score & Category & Frequency & Percentage $(\%)$ \\
\hline 1 & $81-100$ & Very Good & 7 & 24,9 \\
\hline 2 & $66-80$ & Good & 13 & 50,2 \\
\hline 3 & $51-65$ & Enough & 7 & 24,9 \\
\hline 4 & $0-50$ & Not Good & 0 & 0,0 \\
\hline \multicolumn{3}{|c|}{ Total } & 9 & 100,0 \\
\hline
\end{tabular}

Based on the table above it can be described that the critical thinking skills of 27 students in a small group there are 7 students $(24.9 \%)$ with excellent categories, 13 students $(50.2 \%)$ with good categories, and 7 students $(24.9 \%)$ with enough categories.

While the Test of attractiveness, simplicity, and usefulness is done by spreading the student response questionnaire. The results of the students' responses to the Worksheet based on Problem Based Learning are as follows. Questionnaire Student Response to the Worksheet based on Problem Based Learning.

Table 6. Victory, Ease, and Benefit Test Results

\begin{tabular}{|c|l|c|c|c|c|c|c|}
\hline \multirow{2}{*}{ No } & \multicolumn{2}{|c|}{ Category } & \multicolumn{2}{l|}{ Attractive } & \multicolumn{2}{l|}{ Easiness } & \multicolumn{2}{c|}{ Usefulness } \\
\cline { 3 - 8 } & & $\mathrm{F}$ & $\%$ & $\mathrm{~F}$ & $\%$ & $\mathrm{~F}$ & $\%$ \\
\hline 1 & Very interesting / very easy / very useful & 19 & 70,3 & 8 & 29,6 & 18 & 66,7 \\
\hline 2 & Interesting / easy / useful & 4 & 14,8 & 19 & 70,3 & 9 & 33,3 \\
\hline 3 & Quite interesting / easy enough / quite useful & 4 & 14,8 & 0 & 0,0 & 0 & 0,0 \\
\hline 4 & Less attractive / less easy / less useful & 0 & 0,0 & 0 & 0,0 & 0 & 0,0 \\
\hline 5 & Not interesting / not easy / not useful & 0 & 0,0 & 0 & 0,0 & 0 & 0,0 \\
\hline \multicolumn{2}{|c|}{ Average score } & \multicolumn{2}{|c|}{4.56} & \multirow{2}{*}{4.17 (Easy) } & $\begin{array}{c}4.43 \\
\text { (Very Useful) }\end{array}$ \\
\hline
\end{tabular}

In the table above, it appears that the average aspect of attractiveness is 4.57 with a very interesting category, an average aspect of ease of 4.17 with the easy category, and an average benefit aspect of 4.43 with a very useful category. The results of the analysis show that the Worksheet based on Problem Based Learning product trials is extended to large groups, in general, it is very interesting, easy, and very useful for students. Thus, Worksheet based on Problem Based Learning is good and appropriate to use.

\subsubsection{Operational Product Revision}

Done after major field trials to improve the product, taking into account comments and suggestions during previous trials.

\subsection{Effectiveness Integrated thematic learning tools}

The product effectiveness test was conducted to see a significant increase in students' critical thinking skills 
viewed from student learning outcomes before and after learning using thematic learning tools. The recapitulation of student learning data shows an increase in learning outcomes which also shows the results of students' critical thinking skills after learning to use student worksheets based on theme 3 that is 'Care for Living Things' and subtheme 1 that is 'Animals and Plants in My Home Environment'. The average pretest learning outcomes of students in grade 4 were 57 and posttest results increased to 73.3 with an average N-Gain of 0.37 (medium category).

\subsection{Discussion}

\subsubsection{Product Development of Integrative Thematic Learning Tools Based on Problem Based Learning}

This research is a research development, the development is carried out by analyzing the observational data. In the initial field study, information was obtained that (1) the quality of the learning process was still low. (2) The ability to think critically in low category students. (3) The ability of teachers to develop integrative thematic learning tools is still weak. (4) The systematic integration of thematic learning tools not yet prepared by the government. (5) The unavailability of integrative thematic learning tools based on the Problem Based Learning approach in Public Elementary School 3 Argomulyo. Therefore, the authors develop a thematic-integrative learning tool based on Problem Based Learning in the fourth grade of Public Elementary School 3 Argomulyo.

The development of this learning device pays attention to various things that must be present as provisions in making learning devices. The learning tools developed to refer to the Curriculum2013, with a scientific approach, authentic assessment, and paying attention to the three domains of student competency, which are attitudes, knowledge, and skills. The design of syntax, design, and materials and thematic-integrative learning tools based on Problem Based Learning use a thematic learning approach that is integrated with the Problem Based Learning learning model.

The stages of learning in Problem Based Learning enable students to learn independently and be able to solve problems, thereby providing meaningful knowledge and leads to improved student learning outcomes. This is in accordance with the opinion of Arends (2012: 398-399) which states the main objectives of Problem Based Learning are (a) developing thinking and problem-solving skills, (b) helping students learn to take on the role of adults and social skills (adult role behavior and social skills), and (c) help students develop skills for independent learning (skills for independent learning).

\subsubsection{Effectiveness of Integrative Thematic Learning Tools Based on Problem Based Learning}

The effectiveness of teaching material in learning is seen from whether or not the student's learning outcomes increase after using the teaching material. To determine the effectiveness of the use of thematic-integrative learning tools based on Problem Based Learning by looking at the level of learning outcomes obtained by students before and after participating in learning using the Problem Based Learning model. Effectiveness test is used to see the ability to think critically, and student learning outcomes. The effectiveness test was conducted on 27 students in the fourth grade of Public Elementary School 3 Argomulyo. Based on the effectiveness test using the N-Gain, it is obtained that the learning outcomes and critical thinking skills of students after using Worksheets based on Problem Based Learning are higher than before using Worksheets based on Problem Based Learning.

This is based on the recapitulation of student learning outcomes of large groups (page attachments) obtained an average N-Gain of 0.37 in the medium category. There is an increase in student learning outcomes before (pretest) and after (posttest) using a Problem Based Learning Worksheet. The results of the observation of critical thinking skills (attachment page) that the critical thinking skills of 27 students in a large group there are 4 students $(14.8 \%)$ with a very good category. There were 18 students $(66.7 \%)$ in the good category and 5 students $(18.5 \%)$ in the sufficient category. Thus that there is an increase in student learning outcomes and critical thinking skills before and after using the Worksheet based on Problem Based Learning in the fourth grade of Public Elementary School 3 Argomulyo.

This finding is supported by the opinion of Duch, et.al (2001: 6) that Problem Based Learning aims to help students develop critical thinking skills, analyze and solve complex real-world problems. Strengths of Development of Integrative Thematic Learning Tools Based on Problem Based Learning. And Limitations in the Development of Integrative Thematic Learning Tools Based on Problem Based Learning.

\subsection{Excess the Development of Integrative Thematic Learning Tools Based on Problem Based Learning}

(1) the Development of Integrative Thematic Learning Tools Based on Problem Based Learning that are developed in accordance with the 2013 Curriculum and according to students' needs. (2) Learning activities using thematic-integrative learning tools based PBL contain learning components namely problem orientation, organizing students to learn, guiding individual experiences, developing and presenting their work, and analyzing and evaluating problem solving processes. (3) The material in worksheets uses simple, clear, and easyto-understand language in constructing knowledge (4) worksheets in accordance with the objectives of making it easier for students to understand the material presented. This shows that the worksheet can motivate students and 
not make them bored with learning. (5) worksheet based on PBL help and simplify the learning process and improve students' critical thinking skills.

\subsection{Limitations on Development of Integrative Thematic Learning Tools Based on Problem Based Learning}

(1) Core competencies and basic competencies in Development of Integrative Thematic Learning Tools Based on Problem Based Learning only develop one sub-theme with 4 learning. (2) Product trials are only 4 meetings so that learning outcomes are less than optimal. (3) Limitations in compiling research instruments and research instruments that have been tested only once so as to allow errors and seriousness to respond to the instrument. (4) Population limitations in testing the effectiveness of thematic-integrative learning tools are only done in one school.

\section{CONCLUSION}

Based on the results of research on the development of thematic-integrative learning tools based on problem based learning on the sub-themes of animals and plants in my home environment of fourth grade in Public Elementary School 3 Argomulyo, Banjit District, Way Kanan District, it can be concluded as follows: 1) Product development of learning devices Thematic-integrative Problem Based Learning developed based on needs analysis, assessment of learning experts consisting of material experts and media experts, curriculum experts, teacher validation, and student responses, is declared valid as a learning tool used in the learning process in fourth grade Public Elementary School 3 Argomulyo. 2) The product development of thematic-integrative learning tools based on Problem Based Learning that is produced is effectively used in the learning process of fourth-grade students in Public Elementary School 3 Argomulyo. This is proved by the increased learning outcomes of fourth-grade students in learning the sub-theme "animals and plants in my home environment".

\section{SUGGESTION}

The development of thematic-integrative learning tools based on Problem Based Learning requires creative educators to present material, have abilities and skills, actively engage students according to low, medium, and high absorbency.

\section{REFERENCES}

Akınoğlu, O. \& R. O. Tandoğan. (2007). The effects of Problem-Based Active Learning in Science Education on Students Academic Achievement, Attitude and Concept Learning. Eurasia Journal of Mathematics, Science \& Technology Education, 2007, 3(1), p. 71-78.

Borg, W. R. \& Gall, M. D. (1983). Educational research: an introduction (4thed). New York \& London: Longman Inc.

Departemen Pendidikan dan Kebudayaan. (2013). Peraturan Menteri Pendidikan dan Kebudayaan No 65 Tahun 2013 tentang Standar Proses.

Departemen Pendidikan dan Kebudayaan. (2013). Peraturan Menteri Pendidikan dan Kebudayaan RI Nomor 71 Tahun 2013, tentang Buku Teks Pelajaran Dan Buku Panduan Guru Untuk Pendidikan Dasar Dan Menengah.

Lumsdaine, E. \& M. Lumsdaine. (1995). Creative Problem Solving Thinking Skills for Changing World. Singapore: McGraw-Hill.

Moore, B. \& T. Stanley. 2010. Critical Thinking \& Formative Assessments. New York: Eye on Education, Inc.

Neuman, D. (2011). Learning in Information-Rich Environment, I-LEARN and the Construction of Knowledge in the $21^{\text {st }}$ Century. New York: Springer.

Nitko, A.J. \& S. M. Brookhart. (2011). Educational Assessment of Students ( $6^{\text {th }}$ edition). Boston: Pearson Education Inc.

OECD. (2010). PISA 2009 at a Glance. OECD Publishing. http://dx.doi.org/ 10.1787/9789264095298-en.

Sukmadinata, S. N. (2012). Metode penelitian pendidikan. Bandung: PT Remaja Rosdakarya.

Sundayana. 2015. Statistika Penelitian Pendidikan. Bandung: Alfabeta.

Sutriningsih, Naning. 2015. "Penerapan Model Pembelajaran Team Assisted Individualization Berbasis Assesment For Learning Pada Persamaan Garis Lurus Ditinjau Dari Karakteristik Cara Berpikir". Jurnal eDu Math. 1.1.

Tiarani (2013). Penerapan Metode Discovery Untuk Meningkatkan Hasil Belajar Siswa SD Pada Mata Pelajaran Matematika Materi Pokok Bangun Ruang. (Penelitian Tindakan Kelas Di Kelas IV SDN Barunagri Lembang) Bandung: UPI.

Torp, L. \& S. Sage. (2002). Problem as Possibilities, Problem-Based Learning for K-16 Education (2 $2^{\text {nd }}$ edition). Alexandria: Association for Supervision and Curriculum Development (ASCD).

Uzuntiryaki-Kondakçi, E. \& Çapa-Aydin, Y. (2013). Predicting Critical Thinking Skills of University Students 
through Metacognitive Self-Regulation Skills and Chemistry Self-Efficacy. Journal of Educational Sciences: Theory \& Practice - 13(1). p. $666-670$.

Wahab, Abdul. (2014). Analisis Kebijaksanaan dari Formulasi ke Implementasi Kebijaksanaan Negara. Jakarta: Bumi Aksara. 